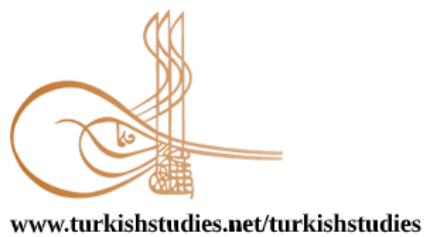

Turkish Studies

www.turkishstudies.net/turkishstudies

eISSN: 1308-2140

BALKAN
UNIVERSITY

Sponsored by IBU

Research Article / Araştırma Makalesi

\title{
II. Dünya Savaşı Akabinde Türkiye’de Sağlık Durumu ve Salgın Hastalıklarla Mücadele (1946-1950)
}

\author{
After II World War and Health Status in Turkey Against Disease Outbreak 1946-1950
}

\author{
Cengiz Atl1 ${ }^{*}$ - Fuat Kahraman ${ }^{* *}$
}

\begin{abstract}
The War of Independence, which started after the occupation of Anatolia by the Allied Powers after the First World War, resulted in victory and Anatolia was saved from the enemy invasion. The newly established they started to work for the solution of the serious problems experienced in the field of health as well as the Republic of Turkey in every field. In this context, the laws required for the establishment of a health organization were enacted in the first years of the Republic. In addition, efforts were made to combat infectious diseases, to develop preventive health services and to train the needed health personnel. In the following years, efforts were made to expand the health services all over the country, to open health houses to villages, health centers to districts, and hospitals to provincial centers. In addition, efforts to assign health personnel to these health institutions continued. Public spending in the field of health was increasing steadily in proportion to the need since 1946. In line with the issues announced by Prime Minister Recep Peker in the government program, a 10-year health plan was prepared by the Ministry of Health in 1946. With the prepared health plan, hospitals, prevantorians, polyclinics, resting places, maternity centers will be established in each region, as well as special combat teams and research centers for epidemics in that area. Schools and courses would also be opened in order to train nursing and health officials as required by the plan. In this period, the main institution became health centers in the work program prepared with health. These centers, which will have all kinds of fixed and mobile vehicles and equipment and equipment for protecting public health, are also equipped with all the first aid vehicles and staff, and they are equipped with the most modern formations that gather all means and facilities of the science all over the country by entering the village next to the village and rising gradually. He was trying to protect the trust and trust of the Turkish citizen in his country. The biggest problem waiting period in the Republic of Turkey in the field of health, disease outbreaks were caused by infectious diseases. Due to the humane, socio-economic and strategic importance of combating infectious diseases, a very important struggle was fought under difficult conditions. With this struggle in the first years of the Republic, the disease was significantly controlled.
\end{abstract}

Structured Abstract: The War of Independence, which started after the occupation of Anatolia by the Allied Powers after the First World War, resulted in victory and Anatolia was saved from the enemy invasion. The

\footnotetext{
${ }^{*}$ Doç. Dr. Iğdır Üniversitesi Fen/Edebiyat Fakültesi Tarih Bölümü

Assoc. Prof. Dr. I $\breve{g} d \imath$ r University, Faculty of Science, Literature, Department of History

ORCID 0000-0001-7617-6879

cengiz3636@hotmail.com

**Dr. Öğr. Üyesi, Iğdır Üniversitesi, Sağlık Bilimleri Fakültesi, Hemşirelik Bölümü

Asst. Prof. Dr., Iğdır University, Faculty of Health Sciences, Department of Nursing

ORCID 0000-0002-7255-1149

fuatkahraman@igdir.edu.tr

Cite as/ Atıf: Atlı, C., Kahraman, F. (2020). II. Dünya Savaşı akabinde Türkiye'de sağlık durumu ve salgın hastalıklarla mücadele (1946-1950). Turkish Studies, 15(4), 39-55. https://dx.doi.org/10.7827/TurkishStudies.43677

Received/Geliş: 18 May/Mayıs 2020

Accepted/Kabul: 10 August/Ağustos 2020

Copyright $\mathbb{C}$ MDE, Turkey

Checked by plagiarism software

Published/Yayın: 30 August/Ağustos 2020

CC BY-NC 4.0
} 
newly established they started to work for the solution of the serious problems experienced in the field of health as well as the Republic of Turkey in every field. The main task of the state health services in Turkey are not addressed in the Grand National Assembly (GNA) began with the opening. The UNM, which was opened on April 23, 1920, passed the Ministry of Health and Social Affairs (Health and Social Aid) Ministry with the law no. After the establishment of the Ministry of Health, he was the first Minister of Health. Adnan Adivar was appointed as minister. Dr. Adnan Adıvar started his duty as a minister in a room of the Ankara provincial mansion on 11 May 1920. Dr. Adnan Adivar firstly, to determine the number of physicians working in the country, and began to examine all the laws and regulations of the Istanbul Government regarding health affairs.

In this context, the laws required for the establishment of the health organization in the first years of the Republic were also enacted and implemented. In addition, efforts were made to combat infectious diseases, to develop preventive health services and to train the needed health personnel. In the following years, efforts were made to expand the health services all over the country, to open health houses to villages, health centers to districts, and hospitals to provincial centers. In addition, efforts to assign health personnel to these health institutions continued

health studies in Turkey II. It began to gain more importance during World War II. Although Turkey II. Although he did not participate in World War II, he faced significant difficulties in health, social and economic areas. These difficulties affected public health negatively and caused a decrease in quality of life. The emerging nutritional deficiencies and the inadequate sanitary conditions of the houses accelerated the spread of epidemics, especially tuberculosis disease. After the World War, important developments in the field of health, he served as minister between 1946-1950. It was implemented in the light of the "First Decade of Health Plan" prepared and implemented by Behçet Uz. With this plan, it was aimed to integrate health services and spread it across the country. In addition, all of the health services were taken under the duties and responsibilities of the government. According to the plan, the country would be divided into seven health zones and the organization of each zone would be self-sufficient. In these regions, a 10-bed health center will be established for 40 villages and 2 physicians, 1 midwife, 1 health officer and a visiting nurse will be assigned to these centers. In addition, a midwife and a health officer would be assigned for each of the 10 villages. In this period, the main institution was the health centers in the work program prepared with health. These centers, which will have all kinds of fixed and mobile vehicles and equipment and equipment for public health protection, are also equipped with all the first aid vehicles and staff, and they are equipped with the most modern formations that gather all means and facilities of the science all over the country by entering the village next to the village and rising gradually. He was trying to protect the trust and trust of the Turkish citizen in his country.

The biggest problem waiting period in the Republic of Turkey in the field of health, disease outbreaks were caused by infectious diseases. Since 1946, the Ministry of Health has tried to take every precaution it deems necessary to combat infectious diseases such as Typhus, Tifo Çiçek, Horse plague and similar diseases in the country. There were a lot of typhoid and smallpox vaccines in ministry institutions. Infectious diseases specialists traveled around the provinces and immediately underwent strict screening and intervention in places where the disease was observed. When these diseases, which are common in a certain region in our country, rise above the normal level, the ministry warned the public and the public's demand for vaccination facilitated the ministry's job in the struggle. Teams were prepared in the fields necessary to combat typhus disease and 6 million vaccines were stocked. In addition, D.D.T was fighting bit where necessary. The publication titled "Health Propaganda" was published by the ministry in order to raise the awareness of the public about epidemics. After this publication, "Water hygiene. Brochures named "Rabies Disease and Prevention Methods" were published and distributed to the public in cities, towns and villages, to army members, schools, public and private institutions with communities and workers. In addition, collaboration was conducted with foreign scientists to combat epidemics. In this context, British expert Mr. R. Daubney came to our country and started to work on Bacteriology and Serology at the Ministry of Agriculture.

In the post-war years, there was a significant increase both in annual expenditure per capita and in the budget allocated to the Ministry of Health and Social Aid. Public spending in the field of health had increased steadily since 1946. The Ministry of Health budget for the first time reached $4.4 \%$ of the budget in 1950 . The appropriation allocated for health in 1950 was 60.980 .329 lira. Therefore, the budget expenditure, which was $3.23 \%$ in 1946 , increased to $4.15 \%$ in 1950 . The upward trend in the period 1946-1950 increased significantly in 1949. During this period, a draft of a regulation that would regulate the specialization of physicians was 
prepared. In order to prepare the regulation, a commission was formed with some professors from Ankara and Istanbul Medical faculties. In addition, courses were opened to ensure the development of doctors working in the Healthcare Organization. In this context, the First Evolution course was opened in the Hygiene School, hospital doctors, health center and doctors struggling with the Malaria War participated in this course.

Keywords: Health, Epidemic, Struggle, Infectious, Disease, Vaccine Prevention.

Öz: Birinci Dünya Savaşı'ndan sonra Anadolu'nun itilaf devletlerince işgal edilmesi sonucu başlayan Kurtuluş Savaşı zaferle sonuçlanmış ve Anadolu düşman işgalinden kurtarılmıştı. Yeni kurulan Türkiye Cumhuriyeti her alanda olduğu gibi sağlık alanında da yaşanan ciddi sorunların çözümü için çalışmalara başladı. Bu kapsamda Cumhuriyetin ilk yıllarında sağlık teşkilatının oluşturulması için gerekli olan kanunlar çıkarılarak uygulamaya konuldu. Bunun yanı sıra bulaşıcı hastalıklarla mücadele, koruyucu sağlık hizmetlerinin geliştirilmesi ve ihtiyaç duyulan sağlık personelinin yetiştirilmesi çalışmaları yapıldı. Sonraki yıllarda sağlık hizmetlerinin ülkenin her yerine yaygınlaştırılması çalışmaları kapsamında köylere sağlık evi, ilçelere sağlık ocağı ve il merkezlerine hastane açılması çalışmaları yapıldı. Ayrıca bu sağlık kuruluşlarına sağlık personeli görevlendirme çalışmaları devam etti. Sağlık alanında kamu harcamaları da ihtiyaç nispetinde 1946 yılından başlayarak düzenli bir artış göstermekteydi. Başbakan Recep Peker’in hükümet programında açıkladığı hususlar doğrultusunda 1946 yılı Sağlık Bakanlığı tarafından 10 yıllık bir sağlık planı hazırlandı. Hazırlanan sağlık planı ile her bölgede hastaneler, prevantoryanlar, poliklinikler, dinlenme yerleri, doğumevleri kurulacağı gibi ayrıca o bölgeye salgın hastalıklar için özel mücadele ekipleri ve araştırma merkezleri de yapılacaktı. Yine plan gereğince hastabakıcı ve sağlık memurları yetiştirmek amacıyla okullar ve kurslar açılacaktı. Bu dönemde sağlık ile hazırlanan çalışma programında ana kurum sağlık merkezleri olmuştu. her türlü sabit ve gezici vasıtalarla halk sağlı̆̆ını koruma malzeme ve tertibatına sahip olacak bu merkezler aynı zamanda bütün ilk yardım araç ve elemanlarıyla teçhiz edilmiş olarak köyde köylünün yanında hizmete girerek ve kademe kademe yükselerek ülkenin dört yanında fennin bütün vasıta ve imkanlarını içinde toplayan en modern oluşumlarla Türk vatanında Türk vatandaşının İtimat ve güvenini korumaya çalışmaktaydı. Bu dönemde Türkiye Cumhuriyeti'ni sağlık alanında bekleyen en büyük sorun, bulaşıcı hastalıkların neden olduğu salgın hastalıklardı. Bulaşıcı hastalıklarla mücadelenin insani, sosyo-ekonomik ve stratejik öneminden dolayı zor şartlar altında oldukça önemli bir mücadele verilmişti. Cumhuriyet'in ilk yıllarındaki bu mücadele ile hastalık önemli ölçüde kontrol altına alınabilmişti

Anahtar Kelimeler, Sağlık, Salgın, Mücadele, Bulaşıcı, Hastalık, Aşı Önlem.

\section{Giriş}

Selçukluların Anadolu'da kurdukları ilk sağlık kurumu Kayseri'de 1206 yılında kurulan Gevher Nesibe Sultan Hastanesi ve Tıp Medresesi'dir. Selçuklular 13.yüzyılda Kayseri'den sonra Sivas, Divriği, Konya, Çankırı, Kastamonu, Aksaray, Akşehir, Mardin, Erzurum, Erzincan ve Amasya'da da hastaneler kurmuşlardır. Bu sağlık kurumlarında hem hastaların tedavileri yapılır hem de usta-çırak yöntemi ile hekimlerin yetiştirilmesi sağlanırd1.13.yüzyıl ve sonrasında Anadolu'da sultanlar, beyler ve zenginler de vakıf hastaneleri kurarak toplumun sağlık ihtiyaçlarına katkıda bulunmuşlardı. (Nusret H. 1983,s.155) Osmanlı Devleti’nde 15.yüzyıldan itibaren yaklaşık 400 y1l boyunca devletin sağlık alanıyla ilgili işleri hekimbaşılar tarafından yürütülmekteydi. Hekimbaşıların atamaları sadrazamların önerisiyle padişah tarafından yapılırdı. Hekimbaşılar, 19.yüzyıl ortalarına kadar ülkenin bütün asker ve sivil sağlık işlerinden sorumlu olmuşlardı. Osmanlı Devleti nde sağlık mevzuatı ile ilgili ilk çalışmalar, Sultan II. Mahmut döneminde 1838 yılında çıkarılan ve ilk sağlık yasası olan "Karantina Nizamnamesi” ile başlamıştır. 1871 yılında çıkarılan "Sıhhiye Müfettişleri” ve "Memleket Tabiplikleri Kurulması ve Atanması Hakkında İdare-İ Umumiye-İ Tıbbiye Mülkiye Nizamnamesi”'(Sivil Tıp Hizmetleri Genel Yönetim Tüzüğü) ile sağlık hizmetlerinin ilçelere kadar yayılması sağlanmıştı. (80. Yılda Tedavi Hizmetleri (1923-2003). 2004, s.4) 
Osmanlı Devletinde sağlık alanında idari çalışmaların yanı sıra tedavi edici sağlık hizmetleri alanında da çalışmalar yürütülmekteydi. Bu kapsamda 1845 yılında Haydarpaşa Askeri Hastanesi, 1862 yılında da Zeynep Kamil Hastanesi hizmete açıldı. Bu gelişmelerle darüşşifadan hastaneye geçişle sağlık hizmetlerinin devlet eliyle verilmesi devletin sağlik hizmeti sunması açısından önemli bir başlangıç olmuştur. Çalışma yapılan diğer bir alan da koruyucu sağlık hizmetleri alanı idi. Bu kapsamda 1889 yılında salgın hastalıklarla mücadele amacıyla çiçek aşısı üretim merkezi olan Telkihane-i Şahane 'nin kurulması yönünde yasa tasarısı hazırlanmış ve bu kurum 1892 yılında II. Abdülhamid'in emriyle hizmete girmişti. Ayrıca 1892 yılında "buharla dezenfeksiyon yapılan yer" anlamına gelen tebhirhane kurulmuştur.1893 yılında kolera salgınının başlamasıyla "Bakteriyolojihane-i Şahane" yapılandırılarak Osmanlı Devleti'nde koruyucu hekimliğin temeli atılmıştır. (Gamze. 2008, s.165-177)

Osmanlı Devletinde Birinci Meşrutiyet (1876) ve İkinci Meşrutiyet (1908) sağlık alanında önemli gelişmelerin yaşandığı dönemler olmuştur. Bu dönemlerde özellikle İtalya örnek alınarak sağlık teşkilatı yeniden yapılandırılmış ve 1914 yılında genel müdürlük statüsünde olan sağlık teşkilatı bakanlık düzeyine yükseltilmiştir. Bu dönemde sağlık teşkilatı İçişleri Bakanlığı ile birlikte teşkilatlandırılarak Dâhiliye ve Sıhhiye Nezareti adıyla çalışmalarını sürdürmüştür. (Kasapoğlu, 2016, s.134)

\section{Türkiye'de Sağlık Durumu (1923-1946)}

Türkiye'de sağlık hizmetlerinin devletin temel görevi olarak ele alınması Büyük Millet Meclisinin (BMM) açılmasıyla başladı. 23 Nisan 1920`de açılan BMM, 2 Mayıs 1920 tarihinde kabul ettiği 3 nolu kanunla, Sıhhiye ve Muaveneti İçtimai (Sağlık ve Sosyal Yardım) Bakanlığı’nı kurarak sağlık hizmetlerinin yürütülmesi görevini bu bakanlığa devretti. (TBMMZC, I. I/ 9, s.185-186) Sağlık Bakanlığı’nın kurulmasından sonra ilk Sağlık Bakanı olarak Dr. Adnan Adıvar bakan olarak görevlendirildi. Dr. Adnan Adıvar, 11 Mayıs 1920 tarihinde Ankara vilayet konağının bir odasında bakan olarak görevine başladı. Dr. Adnan Adıvar ilk olarak, ülkede görev yapan hekimlerin sayısını tespit ederek İstanbul Hükümetinin sağlık işleri ile ilgili bütün kanun ve nizamnamelerini incelemeye başladı. (80.Yılda Tedavi Hizmetleri (1923-2003), s.4) Sağlık ve Sosyal Yardım Bakanlığı bu dönemde bakanlık teşkilatını kurmak ve geliştirmek, doktor ve diğer sağlık personeli açığını kapatmak, yetim ve göçmenlere yardım etmek, yurtdışından gelebilecek hastalıklara karşı önlem alma çalışmaları yürütmekteydi. (Özpekcan, 2002, s.761) şekilde idi:

Cumhuriyetin kurulduğu 1923 yılında, Türkiye`deki yataklı tedavi kurumlarının sayısı şu

Tablo 1: 1923 yılında, Türkiye`deki Yatakl1 Tedavi Kurumları

\begin{tabular}{|l|l|l|}
\hline İsim & Sayı & Yatak Sayısı \\
\hline Devlet Hastanesi & 3 & 950 \\
\hline Belediye Hastanesi & 6 & 635 \\
\hline Özel İdare Hastaneleri vabancı ve Azınlık & 45 & 4520 \\
\hline $\begin{array}{l}\text { Özel, Yabanc } \\
\text { Hastaneleri }\end{array}$ & 32 & 2402 \\
\hline Toplam & 86 & 6437 \\
\hline
\end{tabular}

Kaynak: 80.Yılda Tedavi Hizmetleri (1923-2003), s.6

1923 yılında ülkemizde toplam 554 hekim görev yapmaktaydı. Bir hekime düşen kişi sayısı 19.860 idi. Ülkedeki toplam eczacı sayısı 60 ve bir eczacıya düşen kişi sayısı da 159.420 idi. Ayrıca ülkedeki ebe sayısı 136, hemşire sayısı da 42 idi. (Ak, 2002. s.729)

Cumhuriyetin ilk y1llarında Türkiye de yaygın olarak görülen hastalıklar sıtma, frengi, trahom hastalıkları idi. Sitma ile mücadele kapsamında 1925 yılında Ankara, Adana Aydın, Samsun ve Kocaali'de bulunan sitma mücadele merkezlerinde 66.578 kişi sitma hastalığ 
ve 35.629 hasta tedavi edilmişti. 1928 yılında Ankara, Adana Aydın, Samsun ve Kocaeli sıtma mıntıkalarına Konya ve Bursa da eklenmişti. Sitma hastalığı ile mücadele kapsamında 771.924 kişi sitma muayenesi olmuş ve tedavi edilen hasta sayısı 100.898 olmuştur. Trahom hastalığ ile mücadele için de Adıyaman ve Malatya'da merkezler kurulmuştu. Adıyaman'da 1927 yılında merkezde tespit edilen hasta sayısı 2.668 iken seyyar teşkilat tarafından 48 köyde tespit edilen hasta sayısı 1.564 kişi idi. 1928 yılında Adıyaman merkezde hasta sayısı 4.123 olmuştur. Malatya' da ise 1927 yılında 2.566 kişide hastalık tespit edilmiştir.1928 yılında ise bu sayı 2.483 olmuştur. Yaygın olarak görülen diğer bir hastalık olan frengi hastalığı ise 1926 yılında 2.836 kişide 1928 de 4.041 kişi de görülmüştür. Hastalıkla yapılan mücadele sayesinde 1928 yılında hastalık görülen kişi sayısı 1.121 olmuştur. (Başvekâlet İstatistik Umum Müdürlüğü 1929 İstatistik Yılllğı s.86-87)

Sağlık teşkilatının örgütlenme çalışmaları ve sağlık hizmetlerinin tüm ülkeye yayılması çalışmaları Dr. Refik Saydam`ın sağlık bakanlığı yaptığı dönemde hız kazandı. Adnan Adıvar’dan sonra 1921 yılında sağlık bakanı olarak atanan Dr. Refik Saydam, kısa süreli aralıklar dışında 1937 yılına kadar sağlık bakanı olarak görevini sürdürdü. Bu dönemde illerde sağlı müdürleri, ilçelerde hükümet tabiplikleri kurularak sağlık örgütünün temel taşları oluşturuldu. Yataklı tedavi hizmetlerinin kamu eliyle ancak yerel idareler tarafından yürütülmesi politikası benimsendi. 1928 yılında "Tababet ve Şuabatı Sanatlarının Tarzı İcrasına Dair Kanun” çıkarılarak, sağlık personelinin yetki ve sorumlulukları belirlendi. 1930 yılında "Umumi Hıfzıssıhha Kanunu" çıkarılarak sağlık hizmetlerine ait politikaların esasları belirlendi. 1936 yılında da "Sağlık, Sosyal ve Yardım Bakanlığı Teşkilatı ve Memurin Kanunu" çıkarıldı. Bu kanunla da bakanlığın merkez ve taşra örgütünün kuruluşu tamamlanarak bakanlığın yetki ve sorumluluklarına açıklık getirildi. (Akdur,1999, s.50) 1936 y1lında ülkedeki doktor sayısı 1287, ebe sayısı 471, hemşire sayısı 357 idi. Ayrıca eczacı sayısı 135, sağlık memuru sayısı 1405 ve diğer memur sayısı da 734 idi. (Başbakanlık İstatistik Genel Müdürlüğü (1937 İstatistik Yıllığı s.94)

\section{6-1950 Yıllarında Ülkemizin Sağlık Durumu}

Türkiye her ne kadar II. Dünya Savaşı'na katılmamış olsa da sağlık sosyal ve ekonomik alanda önemli zorluklarla karşılaşmıştı. Yaşanan bu zorluklar halk sağlığını olumsuz etkilemiş, yaşam kalitesinde düşüşe neden olmuştu. Ortaya çıkan beslenme yetersizlikleri ve evlerin sıhhi durumlarının uygun olmayışı verem hastalığ 1 başta olmak üzere salgın hastalıkların yayılmasını hızlandırmıştı. II. Dünya Savaşından sonra sağlık alanında yaşanan önemli gelişmeler 1946-1950 yılları arasında bakanlık görevini yürüten Dr. Behçet $\mathrm{Uz}$, tarafından hazırlanarak yürürlüğe giren "Birinci On Yıllık Sağlık Planı" 1şığında uygulanmaktaydı. Bu planla sağlık hizmetleri entegre edilerek ülke sathına yayılması amaçlandı. Ayrıca sağlık hizmetlerinin tümü hükümetin görev ve sorumluluğu altına alındı. Plana göre, ülke yedi sağlık bölgesine ayrılacak ve her bölgenin örgütlenmesi kendine yeterli hale getirilecekti. Bu bölgelerde 40 köy için 10 yataklı bir sağl1k merkezi kurulacak ve bu merkezlere 2 hekim, 1 ebe, 1 sağlik memuru ve bir ziyaretçi hemşire görevlendirilecekti. Ayrıca her 10 köy için bir ebe ve bir sağlık memuru görevlendirilecekti. Bu şekilde sağllk merkezleri koruyucu ve tedavi edici hekimlik hizmetlerini birlikte yürütecekti. Bu çalışmalar tamamlandıktan sonra da yedi sağlık bölgesinde de her bir bölge için bir tıp fakültesi kurularak personel yetiştirilmesi de hızlandırılacaktı. Dr. Behçet Uz'un bakanlık görevinden ayrılmasında sonra hazırlanan bu plan gereği gibi uygulanmamış ve çalışmalar her ilçeye bir sağlık merkezi inşa etme şekline dönüşmüştü. (Dirican, 1970, s.189) 1946 yılında Türkiye'de ki doktor sayısı 2.181, eczacı sayısı 137, ebe sayısı 1.110, sağlık memuru sayıs1 2.756, hemşire sayısı 473 ve diğer memur sayısı da 1.377 idi. 1950 y1lına gelindiğinde doktor sayıs1 3.020, eczac1 sayıs1 130, ebe sayıs1 1.285, sağlık memuru sayısı 4.018, hemşire sayısı 721 ve diğer memur sayıs1 da 1.190 oldu. (BİGM, 1951, s.149)

Cumhuriyetin ilk yıllarında yaygın olarak görülen bulaşıcı haslıklarla mücadele çalışmaları bu dönemde de devam etti. Bu kapsamda aşı ihtiyacını karşılamak üzere Refik Saydam Hıfzıssıhha Enstitüsünde yeni bir laboratuvar kuruldu. Kurulan bu laboratuvarda 1946-1950 y1llar1 arasında 
14.789 litre aşı üretildi. Üretilen bu aşılardan kolera salgını için Mısır ve Suriye' ye 1947 yılında 1.300 litre aşı gönderildi. Ayrıca bu dönemde Çin'de görülen kolera salgını için de bu ülkeye bir milyon kişilik kolera aşısı gönderildi. Bu dönemde frengi hastalığı ile mücadele çalışmalarına da devam edildi. 1947 yılında frengiyle mücadele için yeni bir tarama çalışması programı oluşturuldu. Frengiyle mücadelede mevcut olarak kurulan 6 kurul faaliyetlerine devam etmekteydi. Bu kurula da iki motorlu araç tahsis edildi. Ayrıca 1946 yılında 6 adet olan bölge sayısı 1949 da 9 a, koruyucu hekimliğe dair merkez sayısı 10 iken 16 ya yükseldi. Yapılan taramalar sonucu 1948 yılında 170.177 kişide görülen hastalığın yaygınlaşması önlendi. Böylece 1950 yılında frengi hastalığına yakalanan kişi sayıs1 118.169 kişi ye düştü. (BCA. 30.10.14.80.18)

Tifüs hastalığı ile mücadele kapsamında da Refik Saydam Hıfzıssıhha Enstitüsünde bir tifüs laboratuvarı kurularak aşı üretimi çalışmalarına başlandı. Cumhuriyetin ilk yıllarında da en yaygın hastalık olan sıtma hastalığ 1 ile bu dönemde de mücadele edildi.1946 yılında hastalıkla mücadelede DDT, 1949 yılında da mazot ve petrol kullanılmaya başlandı. Yapılan bu çalışmalar neticesinde sıtma hastalığı büyük oranda kontrol altına alındı. Bu dönemde verem hastalığ 1 ile mücadele kapsamında dispanserler açılarak hastalıkla mücadele edildi. Trahom hastalığı önlenmesi çalışmaları kapsamında trahomla mücadele için sağlık kuruluşlarının kapasiteleri arttırılarak hastalıkla mücadele çalışmaları sürdürüldü. Ayrıca kanser hastalığı ile mücadele çalışmaları kapsamında 1947 yılında Türkiye Kanser Araştırma ve Savaş Kurumu kurularak çalışmalarına başladı. (Ak, Türkiye Cumhuriyeti’nde Sağlık Hizmetleri, s.736-737)

\section{Salgın Hastalıklarla Mücadele Çalışmaları}

1946 yılından itibaren ülkede Tifüs, Tifo Çiçek, At vebas1 (BCA. 30.18.1-2.121.83.13) ve benzeri bulaşıcı hastalıklarla mücadele için Sağlık Bakanlığı gerekli gördüğü her tedbiri almaya çalışmışı. Bakanlık kurumlarında çok miktarda Tifo ve çiçek aşısı bulunmaktaydı. İllerde bulaşıcı hastalıklar uzmanları dolaşmakta ve hastalık görülen yerlerde derhal sıkı tarama ve müdahale yapmaktaydı. Ülkemizde belli bir bölgede sık görülen bu hastalıkların normal seviye üstüne çıkması üzerine bakanlık halkı ikaz etmekte ve halkın aşılanmaya rağbet göstermesi bakanlığın mücadeledeki işini kolaylaştırmaktaydı. Tifüs hastalığı ile mücadele için gerekli alanlarda ekiple hazırlanmış ve 6 milyon kişilik aşı stok edilmişti Ayrıca D.D.T ile gerekli yerlerde bit mücadelesi yapılmaktaydı. (BCA. 30.10.178.228.10)

Ayrıca Salgın hastalıklar konusunda halkı bilinçlendirmek amacıyla bakanlık tarafindan "Sağlık Propaganda" isimli neşriyat yayınlandı. Bu neşriyattan sonra "Su hijyeni. Kuduz Hastalığ ve Korunma Yöntemleri” isimli broşürler de yayınlanarak şehir, kasaba ve köylerdeki halka, ordu mensuplarına okullara, halk ve işçi toplulukları bulunan resmi ve özel kurumlara ücretsiz dağıtıldı. Ayrıca salgın hastalıklarla mücadele etmek amacıyla yabancı bilim adamlarıyla da ortak çalışma yürütülmekteydi. Bu bağlamda İngiliz uzman Mr. R. Daubney ülkemize gelerek Tarım Bakanlığında Bakteriyoloji ve Seroloji konularında çalışmalara başladı. (BCA. 30.18.1-2.121.83.13)

Ülkemizde Aralık 1948 tarihinde bulaşıcı ve salgın hastalıkları durumu aşağıdaki şekildeydi. (BCA, 030.10.177.224.10) 
Tablo 2: Ülkemizde 1948 Yılında Bulaşıcı ve Salgın Hastalık Durumu

\begin{tabular}{|l|l|l|l|}
\hline & $\begin{array}{l}\text { Hastalığa } \\
\text { Yakalanan }\end{array}$ & Vefat eden & Ölüm oranı \\
\hline Lekeli Humma & 32 & 1 & 3,1 \\
\hline Tifo & 288 & 33 & 11,4 \\
\hline Dizanteri Gida & 37 & 3 & 8,1 \\
\hline $\begin{array}{l}\text { Paratifo ve } \\
\text { Zehirlenmeleri }\end{array}$ & 14 & -- & --- \\
\hline Sarı Sahayn İltihab1 & 11 & 3 & 27,2 \\
\hline Çiçek & 4 & 2 & 50 \\
\hline Difteri & 101 & 15 & 14,6 \\
\hline Kizıl & 98 & 1 & 1 \\
\hline Kizamık & 615 & 21 & 3,4 \\
\hline Şarbon & 74 & 5 & 6,7 \\
\hline Malta Humması & 3 & --- & -- \\
\hline Çocuk Yaz İshali & 16576 & 95 & 0,6 \\
\hline Cüzzam & 3 & --- & --- \\
\hline Kaynak: & & & \\
\hline
\end{tabular}

Kaynak: BCA, 030.10.177.224.10

1948 yılında nisan ayından aralık ayının sonuna kadar hastalık oranları raporlar halinde sunulmuştu. Ülkenin her tarafında sistemli olarak yapılmakta olan bulaşıcı hastalıklar ile ilgili bilgiler raporlar halinde açıklanmakta idi. 1948 yılının mart ayında tespit edilen oranlar geçen yıllara göre düşük seviyede idi. Salgın amacıyla Doğu illerine ekipler gönderilmişti. Ayrıca Giresun, Çankırı illerinde de birer gezici sağlık ekibi gönderilerek burada belirlenen kişilere D.D.T ve aş1 uygulamaları sürdürülmüştü. tifüs, tifo şarbon, kızamık hummai racia oranı alınan tedbirlerle azalmaya başladı. (BCA. 30.1.77.482.12)

Salgın hastalıklar konusu bu dönemde meclisin de gündemine gelmişti. Bulaşıcı hastalıklar ile mücadelede ne tür tedbirler alındığı konusunda Mardin Milletvekili Dr. Aziz Uras tarafindan meclise bir sözlü soru önergesi verildi. (TBMMZC, 6/79/551) Önergenin bir örneği de Milli Eğitim ve Sosyal Yardım Bakanlıklarına gönderildi. Önerge de kızıl, kızamık, boğmaca, difteri, suçiçeği kabakulak, trahom, tifo, paratifo, verem, dizanteri ve bağırsak parazitleri gibi hastalıkların özellikle okullarda yaygın olarak görüldüğü belirtildi. (BCA. 30.1.53.316.5) Bu hastalıkların belirtileri olan öksürük, nezle, göz kızarıklığı, seste bozukluk, hafif veya yüksek ateş gibi belirtilerin önce çocuğun ailesi sonra okul idaresi tarafindan dikkate alınması gerektiği dile getirildi. Ayrıca bu hastalıkların önlenmesi amacıyla portör muayenesi ve aşı yaptırmak suretiyle büyük ölçüde salgının önlenebileceği açıklandı. Diğer taraftan salgının önlenmesi amacıyla Sağlık Bakanlığının Milli Eğitim Bakanlığı ile ortak çalı̧̧malar yapması gerektiğini açıkladı. (BCA. 30.1.53.316.5) Milletvekilinin öneriyle ilgili son bölümü de veba salgının nasıl bulaştığıyla ilgiliydi. Bu amaçla dört ilde yapılan incelemelerde vebayı sadece pireler değil bit sivrisinek karasinek tahtakurusu ve hamam böceği gibi canlılardan da geçtiğini belirtti. Böylece tifüs, veba, basil ve amip dizanteri, sitma, trahom, verem, hummai racia gibi hastalıklarla mücadele etmek için erken dönemde tedbir alındığı takdirde bu hastalıkların sonlandıracağını açıkladı. (BCA. 30.1.53.316.5)

\section{Hıfzıssıhha Enstitüsünün Salgınla Mücadele Çalışmaları}

Yurt içinde her türlü salgın ve intani hastalıklara karşı koyabilecek koruyucu ve tedavi edici aşı ve serumlar bakanlığa bağlı Merkez Hıfzıssıhha Enstitüsünde hazırlanarak fazla miktarda stoklanmaktaydı. Aşılar komşu ülkeler tarafından da ihtiyaç duyulduğu zaman gönderilmekteydi. Enstitüde 1947 yılı içerisinde 8 milyon kişilikten fazla lekelihumma aşısı, 2 tondan fazla tifo aşısı, 
500 kilo kuduz aşısı, 25.000 dozluk difteri (kuşpalazı) serumu, 75.000 dozluk tetenoz serumu, 30 milyon kişiliğe yakın çiçek aşısıyla birlikte birçok özel aşı ve serum ihtiyaç olan zamanlarda kullanılmak üzere hazırlanmıştı. Kurum ayrıca yıllardan beri ordunun aşı ve serum ihtiyacını da karşılamaktaydı. Aynı yıl içerisinde altı binden fazla kimyevi ve kırk bin bakteriyolojik tahlil yapmıştı.

\section{Salgın Hastalık Türleri}

\section{1-Nekotoryas (Çengelli Kurt Hastalı̆̆ı) ve Kuşpalazı Hastalığı}

Karadeniz Bölgesi'nde Birinci Dünya Savaşından sonra bazı vilayetlerde yerleşen ve etkileri bu döneme kadar gelen Çengelli kurt hastalığına karşıda tespit edilen program dahilinde mücadeleye başlanmıştı. Hastalıkla mücadele etmek için özel bir ekiple tarama ve tedaviler uygulanmıştı. Bu hastalığın ilacı da bakanlık tarafından tamamen ücretsiz dağıtılmıştı. Çocuklara saldıran ve çocuklar üzerinde kötü etkiler bırakan kuşpalazı hastalığı ile de mücadele için aşı kampanyası başlatılmıştı. Hastalıkla mücadele etmek için yurt içinde hastalıklara karşı koyabilecek koruyucu ve tedavi edici aşı geliştirilmişti. Bu hastalıktan korunmak için yetkililer tarafından vatandaşlara duyurular yapılarak çocuklarını bu hastalığa karşı aşılatmaları istenilmişti

\section{2-Çiçek Aşısı}

Ülkemizde II. Dünya Savaşının akabinde salgın hastalıklarla mücadele çalışmaları büyük oranda devam etmekteydi. (BCA. 30.10.186.284.5) Bu dönemde mücadele edilen hastalıklardan bir tanesi de çiçek hastalığıydı. Çiçek hastalığıyla geniş ve esaslı bir mücadele yapılmıştı. Ülkenin her tarafında aşı uygulamalarıyla salgın önlenmeye çalışılmıştı. Bu dönemde sıtma salgınıyla mücadele eden ekipler salgının azalmasıyla birlikte çiçek aşısıyla ilgili mücadeleye yönelmişti. Bu amaçla ülkenin farklı bölgelerinde çiçek aşısı uygulaması başlatıldı. 1946 yılında genel çiçek aşısı uygulaması bütün yurtta tamamlandı. Yeni doğan çocukların tekrar aşı vurulmalarına gerek görülenler için ilkbahar aylarında yeni aşılar vuruldu. Böylece büyük sayıda çocuk ölümlerine neden olan çiçek hastalığı etkili bir aşı kampanyasıyla denetim altına alındı. Ayrıca bulaşıcı hastalıkları taşıyan çeşitli böceklere karşı çalışmalar kapsamında teşkilata 3.000 kilo D.D.T dağıtıldı.

\section{3-Sıtma Hastalığı}

$\mathrm{Bu}$ dönemde sitma hastalığı ile de yoğun bir mücadele yaşanmaktaydı. Sitma hastalığıyla mücadele etmek için 53 ilde, 13.285 köyde 250 doktor, 1277 sitma savaş memuru ve çalışanı ile yoğun bir çalışma başladı. Bu çalışma döneminde 2.381. 000 kişi tedavi ve muayene edildi. Ayrıca sitma hastalığının yayılmasına sebep olan 22.280 dekar bataklık alan kurutularak (BCA. 30.10.179.236.1153) vilayete bağ $1_{1}^{1}$ (BCA.30.18.1-2.107.106.17) 16.928 köyde sitma hastalı̆g görülen kişiler belirlenmeye çalışıldı. 1946 yılında çıkarılan Sıtma Savaş Kanunu (Resmi Gazete, 21 Şubat 1946) ve yaygın D.D.T kullanımı neticesinde sıtma hastalığı oranı \% 10 un altına düştü. 1947 yılında da sitma ile mücadele de arazi 1slahına önem verilerek 1slahı mümkün olmayan bataklık alanlarda sivrisinek sürfelerinin yetişmesine mani olmak için gerekli tedbirler alınmaya başlandı. Ayrıca köy kasaba ve şehirlerde yetişkin sivrisinek ile de mücadele edilmekteydi. Bu şekilde yapılan metodik ve sistemli sıtma mücadelesi geçen yıllara göre daha ileri bir durumdayd. Mücadeleye 1948 yılında kadro sayısı genişletilerek ve daha bol ilaç ve malzeme ile takviye edilerek devam edildi. (BCA.30.10.14.80.18).

\footnotetext{
${ }^{1}$ İsimleri belirlenen 53 il şunlardı. Afyon. Amasya, Ankara, Antalya, Aydın, Balıkesir, Bilecik, Bolu, Burdur Bursa, Çanakkale, Çankırı, Çoruh, Çorum, Denizli, Diyarbakır, Edirne, Elazığ, Eskişehir, Gaziantep, Giresun, Hatay İçel, Isparta, İstanbul, İzmir, Kars, Kastamonu, Kayseri, Kırklareli, Kırşehir, Kocaeli, Konya, Kütahya, Malatya Manisa, Maraş, Mardin, Muğla, Niğde, Ordu, Rize, Samsun, Seyhan, Siirt, Sinop, Sivas, Tekirdağ, Tokat, Trabzon Urfa, Yozgat ve Zonguldak idi.
} 


\section{4-Verem}

Yurt içinde çeşitli bölgelerde yirmi yıldır aralıksız sürdürülen verem mücadelesi bu dönemde de devam etmekteydi. Verem hastalığ i ile mücadele etmek için Ankara, Bursa Adana ve Rize'de bakanlık tarafindan, İstanbul İzmir Samsun illerinde ise mücadele cemiyetleri tarafindan kurulan dispanserler halka faydalı hizmetler vermekteydi. İstanbul ve İzmir'de bulunan resmi kurumlar ve hususi teşebbüslerin kurduğu Sanatoryumlardan da önemli sonuçlar alınmaktaydı. 1945 li yıllara kadar ülkede 3 olan verem dispanseri sayısı 1945 'te 5e 1950 y1lında ise 51 e ulaştı. 1946 y1lında devlet hastanelerinde veremlilere tahsis edilen yatak sayıs1 546 iken 1949 yilında 1097 ye 1950 yılının başında da 1838 'e yükseldi. Bu mücadelede özel idare, belediye ve diğer kuruluşlara ait hastanelerle birlikte toplam 3570 yatak bulunmaktaydı. Verem Savaş Derneklerine mücadelede kullanılmak amacıyla da iki milyon lira yardım yapılmıştı. (Aşgın, 2000, s. 83)

Fakat veremle mücadele yalnızca tedavi ve bakım ile yeterli olmamaktaydı. Bu bağlamda halkında üzerine düşen sorumluluğu yerine getirmesi gerekmekteydi. Ayrıca yetkililer verem ile mücadele etmek amaciyla dispanserler ve hastaneler inşa etmeye başlamışlardı. 1947 yılında Heybeliada sanatoryumu yatak sayısını 250 artırmıştı. Heybeliada Verem Sanatoryumuna 270 yataklı bir bölüm daha ilave edilerek yatak sayısı 520 ye çıkarılmış ve yeni eklenen bölüm Ocak 1947 yılında hizmete açılmıştı. İstanbul'da geniş ölçülerde büyük bir dispanser ve Ankara'da da 200 yataklı bir verem hastanesi hizmete girdi. Hastane bir buçuk milyon lira parayla kuruldu. Ayrıca Cerrahpaşa Hastanesine 200 yataklı bir verem bölümü ilave edilerek kadrosu takviye edildi. Haydarpaşa Numune Hastanesi'nin ek olarak yapılmakta bulunan 100 yataklı ek kısım inşaatı da devam etmekteydi.

Ankara ve İstanbul'dan hariç ülkenin farklı illerinde de verem savaşıyla mücadele etmek için çalışmalar yürütülmekteydi. Bu bağlamda İzmir bulaşıcı ve salgın hastalıklar hastanesi de kadrosunu genişletmekleydi. Kastamonu'da tamir edilmekte bulunan verem hastanesi kadro ve iaşe tahsisatı temin edilince 250 yataklı olarak çalışmalarına devam etti. Trabzon Numune Hastanesi 1947 yılının ilk aylarında açılınca eski hastane 60 yataklı bir verem tecrit hastanesi haline dönüştürüldü. $\mathrm{Bu}$ illerde bulunan devlet ve memleket hastanelerinin kadrolarına röntgen ve pnömotoraks tespit cihazı ilave edilerek her birine 5 tane verem yatağı konularak bu suretle verem hastaları için toplam 150 yatak temin edilmişti. Resmi Sanatoryum ve hastanelerde mevcut bulunan 750 verem yatağına ilaveten eklenen kısımlarla bu rakam 1710'a ulaştı. Ayrıca Adana İstanbul ve Rize verem dispanserlerine röntgen cihazları getirilerek bulundukları hastanelere yerleştirildi. Yapılan çalışmalarla verem ile mücadelede 185.734 tüberkülin testi yapıldı. (Albayrak, 2004, s. 410)

Ülkede sistemli verem hastalığg ile mücadele edebilmek için gönüllü verem derneklerinin bütün ülkeyi teşkili hakkında gerekli valiliklere direktifler verilmişti Bu dönemde Ankara Verem Savaş Derneği'nin tüzüğü yeniden incelenerek son şekli hazırlanmaya çalışılmaktaydı. (BCA.30.10.14.80.18)

Sağlık bakanlığı salgınla mücadelede yurtiçinde olduğu kadar yurtdışında da gereken özeni göstermekteydi. 1946-1947 yıllarında komşu ülkelerde görülen vebadan korunmak ve yurt sağlığını korumak için gerekli bütün tedbirler alınmıştı. Aşılama istasyonları ve ihtiyat aşı stokları kurulmuş kara deniz ve hava yolculularına takibat yapılmıştı. Bakanlık radyo yayın ve sinema gibi vasıtalarla halk sağlık bilgisini geliştirmek için oldukça geniş bir çalışma yapmıştı. Güney sınırımıza yakın yerlerde de bulaşıcı hastalıklara karşı etkin mücadele edebilmek için bütçeden fazla pay ayrılması istenmişti. Akçakale'nin 3 köyünde 15 kişide tespit edilen veba salgınına karşı hastalığın tehlikeli durumu önlenecek çalışmalar başlatılmıştı. Hastalığı bulaştırdığı belirlenen fare ve pirelere karşı Urfa'nın tüm ilçeleriyle birlikte ortak önlemler alınmaya başlandı. (BCA.30.10.177.224.12) 
Bu amaçla Sağlık İşleri Genel Müdürü Akçakale'de Suriye Sağllk müfettişlerinden Dr. Rüştü, Derzor Sağlık Müdürü Dr. Atıf, Tel Abyad doktoru Dr. Raşit Baki ile konuyu görüşmüşlerdi. Bu görüşmede Suriyeli doktorlar Suriye'de veba hastalığı olmadığını ileri sürseler de Akçakale'ye yakın Suriye köylerinde şüpheli ölüm vakaları olduğu öğrenilmişti. Fakat Suriye bu hastalık vakasıyla gerektiği şekilde ilgilenmemişti. (BCA.30.10.177.224.12)

Nitekim Derzor Sıhhiye Müdürü tarafindan Akçakale'de bulunan seyyar laboratuvara getirilen Suriyeli bir hastaya ait muayenede hummai racia olduğu tespit edilmişti. Bu durum üzerine konu Dışişleri Bakanlığına iletilmişti Dışişleri Bakanlığı bu konuyla ilgili Uluslararası Sağlık Teşkilatından bilgi istedi. Uluslararası Sağlık Teşkilatı yaptığı incelemede Akçakale'ye yakın Kırkkaya, ve Varta adlı Suriye köylerinde altı veba hastasının olduğunu belirtti. Bu haber doğrultusunda bu hastalığın güney illerimiz için bir tehlike oluşturacağı bu amaçla ilgili bakanlıkların yardımı ile çok geniş ve ciddi bir mücadelenin yapılması gerektiği ve tehlike ortadan kalkıncaya kadar bu mücadelenin üç ayda bir tekrar edilmesi kararlaştırıldı. Ayrıca bu durum karşısında güney demiryolu trenlerinde gereken tedbirlerin alınması gerektiği ve Suriye ile ortak sınır kapılarının kapat1lması teklif edildi. (BCA.30.10.177.224.12)

Bu dönemde ülkenin sağlık durumunu korumak bakımından özellikle veba, hummai racia ve lekeli humma gibi büyük can kaybına sebep olan hastalıklara karşı mücadele için bakanlığın 1947 yılı bütçesindeki bulaşıcı ve salgın hastalıklar ödeneği ile ödenmesi ve özellikle Urfa'da görülen salgın hastalıkla mücadele için de bakanlıktan ayrıca bütçe ayrılması önerilmişti.

Tablo 3: Urfa' da Salgın Hastalıkla ilgili Bütçede bulunan ve İstenen Ödenek Miktarları

\begin{tabular}{|l|l|l|l|}
\hline Bölüm Madde & Mevcut Ödenek & $\begin{array}{l}11 \text { Nisan 1947 } \\
\text { y1lına } \\
\text { harcanan }\end{array}$ & İstenen Ödenek \\
\hline $661 / 1$ & 490.000 & 257.177 & 800.000 \\
\hline $661 / 2$ & 245.000 & 73.121 .99 & 150.000 \\
\hline $661 / 3$ & 10.000 & 3.744 .00 & 50.000 \\
\hline & & & \\
\hline
\end{tabular}

Kaynak: BCA.30.10.177.224.12

Ayrılacak bütçede 1947 bütçesinin 661. bölümünün 1 maddesine 800.000 2. maddesine 150.0003 . maddesine göre de 50.000 liralık pay ayrılması istendi.

\section{5-Trahom}

Trahom mücadelesinde de olumlu gelişmeler olmasına rağmen ferdi ve içtimai bakımından daha geniş tedbirlere ihtiyaç vardı. (BCA.30.10.179.236.11) Ayrıca bu hastalıkla daha iyi mücadele etmek için üç tane motorlu vasıta temin edilmişti. 1946 yılına kadar tek bir reislik emrinde güney ve güneydoğu da on iki ili ihtiva eden Trahom Mücadele Teşkilatının 1946 yılında tahsilatı artırılarak iki reisliğe bölündü. Bu teşkilatta da personel azlığı bakanlığı meşgul eden önemli konulardan biriydi. $\mathrm{Bu}$ bağlamda trahomla mücadelede çalıştırılacak 130 hasta ilaçlayıcının kadroları tamamlanmıştı. Trahomla mücadelede 1946 yılında 33 olan dispanser sayısı, 1949 da 40 a 35 olan köy tedavi merkezi de 99 a çıkarıld. Mücadeleye başlandığ 1 yıl illerde trahom endeksi \%93 idi. Bu oran 1946 'da da aynı seviyedeydi. Mücadele teşkilatı hastalığa köy tarama ve tedavileri, merkez dispanser ve hastaneleriyle belli oranda müdahale edilebiliyordu. Bu hastalıkla tıbbi mücadele haricinde temizliğe ve hijyene dikkat edilerek hastalı̆̆ın önlenebileceğine inanılmaktaydı. (BCA. 30.10.178.228.10)

\section{6-Lekeli Humma}

Korkutucu olmamakla birlikte birkaç yıldır ülkede endişeli bir durum yaratan lekeli humma salgınına da karşı önleyici tedbirler alınmış ve bütün zorluklara rağmen hastalık insanlara zarar 
veremez bir hale getirilmişti. Hıfzıssıhha Enstitüsünde hazırlanan lekeli humma aşısından geniş ölçüde faydalanılarak hastalığın sona ermesi sağlandı. Özellikle kış dönemlerinde aşılama işi topluluk merkezlerinde daha sıkı ve sürekli olarak uygulandı. Bu dönemde hastalıkla mücadele etmek için stokta 7 ile 8 milyon aşı stoku bulunmaktaydı. Lekeli humma aşısı vatandaşa tamamen ücretsiz olarak uygulanmaktaydı. Ayrıca lekeli humma salgınında bite karşı kullanılan DDT maddesi de geniş ölçüde kullanılmaya başlanmıştı ( BCA.30.10.179.236.11)

\section{7-Çocuk Yaz İshalleri}

Bu dönemde küçük çocuk ölümüne sebep olan çocuk yaz ishallerine karşı oldukça geniş bir mücadele yapılmıştı. Bu hastalık için Hıfzıssıhha Enstitüsünde hazırlanan özel bakteriyofaj ilacı mümkün olan olanaklar ölçüsünde yurdun her tarafına gönderilmişti. Gönderilen ilaçlar sağlık elemanları vasitasıyla halka ücretsiz olarak dağıtılmaktaydı. Bu hastalık ayrıca zorunlu hastalıklar listesine alınarak düzenli bir şekilde hastalığın takibatı sağlanmaya çalışılmıştı. (BCA. 30.10.179.236.11) Ayrıca hastalıkla mücadele etmek için İsviçre ve Amerika'dan ithal edilen ilaçların dışında bu alanda kullanılmak üzere ilaç yapım çalışmaları da başlatılmıştı. Çocuk Yaz ishali mücadelesinde Şubat 1947 yılında 1926 kilo sülfogunidin dağıtımına başlandı.

\section{Sağlık Alanında Yapılan Yatırımlar (Hastane ve Sağlık Ocağı İnşaatları)}

Savaş sonrası yıllarda gerek kişi başına düşen yıllık harcamada gerekse Sağlık ve Sosyal Yardım Bakanlığına ayrılan bütçede belirgin bir yükselme yaşanmıştı. Sağlık alanında kamu harcamaları da 1946 yılından başlayarak düzenli bir artı̧̧ göstermişti. Sağlık Bakanlığı bütçesi ise ilk kez 1950 yılında bütçenin \%4.4 üne ulaşmıştı. 1950 yılında bütçede sağlık için ayrılan ödenek 60.980.329 lira idi. Dolayısıyla 1946 yılı içerisinde bütçe harcaması \%3.23 olan SSYB, 1950 yılında \%4.15 e yükseldi. 1946 -1950 dönemindeki artış eğilim 1949 yılında belirgin biçimde arttı. (Goloğlu, 1982, s. 214)

Tablo 4: 1945-1950 Yıllarında Genel Bütçe İçinde Kişi Başına Düşen Cari ve Reel Sağlık Harcamas1

\begin{tabular}{|l|l|l|}
\hline Yıllar & Kişi Başına Cari Harcama & Kişi Başına Reel Harcama \\
\hline 1945 & 0.99 & 0.22 \\
\hline 1950 & 2.91 & 0.44 \\
\hline
\end{tabular}

Kaynak Sağlık Hizmetlerinde 50 Y11, s.115

Başbakan Recep Peker'in hükümet programında açıkladığı hususlar doğrultusunda 1946 yılı Sağlık Bakanlığı tarafından 10 yıllık bir sağlık planı hazırlandı. Hazırlanan sağlık planı gereği her bölgede hastaneler, prevantoryumlar, poliklinikler, dinlenme yerleri, doğumevleri kurulacağ ayrıca o bölgede görülen hastalıklar için özel mücadele ekipleri ve araştırma merkezleri inşa edilecekti. Yine plan gereğince hastabakıcı ve sağlık memurları yetiştirmek amacıyla okullar ve kurslar açılacaktı. (Nadi, Sağlık Planı, Cumhuriyet 15 Aralık 1946) Bu dönemde sağlık ile hazırlanan çalışma programında ana kurum sağlık merkezleri olmuştu. Her türlü sabit ve gezici vasıtalarla halk sağlı̆̆ını koruma malzeme ve tertibatına sahip olacak bu merkezler aynı zamanda bütün ilk yardım araç ve elemanlarıyla teçhiz edilmiş olarak köyde köylünün yanında hizmete girerek ve kademe kademe yükselerek ülkenin dört yanında fennin bütün vasıta ve imkanlarını içinde toplayan en modern oluşumlarla vatandaşın itimat ve güvenini korumaya çalışacaktı. Ayrıca ekonomik güce göre belirli yıllara bölünerek tesis edilecek ve işletilecek olan bu kurumların hızlı bir şekilde yerleşmesi için Sağlık ve Sosyal Yardım Bakanlığı üzerine düşen görevi yerine getirecekti.

$\mathrm{Bu}$ dönemde sağlık alanına ayrılan gelirin artmasıyla birlikte ülkenin farklı yerlerinde sağlık kurumları açılmaya başlandı. 1946 yılında hem salgın hastalıklarla mücadele edilirken hem de ülkede hastane inşaatları sürmekteydi. Bu bağlamda Şebinkarahisar hastanesi inşaatı tamamlanması için bütçeye ek ödeme yetkisi verildi. Ayrıca Ankara doğum ve çocuk bakımevi inşası da 1947'de tamamlandı. 1947 yılından itibaren iki hastanede tamamlanarak faaliyetlerine başladı. 9 Temmuz 
1945 de kurulan İşçi Sigortaları Kurumu da (Resmi Gazete, 16.07.1945) İstanbul'da açtığı hastane yatak sayısını 1949 da 74 e çıkardı.

Hastanelerden başka sağlık merkezleri kurulma çalışmaları da başlamıştı. Bu bağlamda Düzce Sağlık Merkezi tamamlanarak faaliyetlerine başlamış ve 1 adet motorlu vasıta da sağlık ocağına temin edilmişti. Ayrıca yurdun çeşitli bölgelerinde kurulacak sağlı merkezleri hakkında da gerekli incelemeler yapılmaktaydı (BCA.30.10.14.80.18)1950 yılında sağlık merkezlerinin sayısı 16 ya yükseldi.

Tablo 5: Yatakl1 Tedavi Kurumları

\begin{tabular}{|l|l|l|}
\hline İsim & $\mathbf{1 9 4 5}$ & $\mathbf{1 9 5 0}$ \\
\hline Kurum Sayıs1 & 197 & 201 \\
\hline Yatak Sayı1 & 16133 & 18837 \\
\hline $\begin{array}{l}\text { Yatağa Göre Nüfus } \\
\text { Sayıs1 }\end{array}$ & 1160 & 1100 \\
\hline
\end{tabular}

Kaynak: Cumhuriyet Dönemi Türkiye Ansiklopedisi, s.1123.

1947 y1lında devlet hastanelerindeki yatak sayısı 7703 idi. 1950 yılında da ülke genelinde 20 hastane ve 18.837 yatak mevcuttu. (Kopar, 2009, s. 46) 1950 yılında yatarak tedavi görenlerin sayı1 1 977.757 idi.

Ülkede sağlık alanında görev yapacak eleman yetiştirmek amacıyla da sağlık okulları açılmaktaydı. Ankara'da inşa edilecek olan 300 kişilik sağlık memur okulu plan ve tahsisatı yapılarak 1947 yılında inşaatına başlandı. Ankara İstanbul ve Sivas Sağlık memurları okullarında da inşaatlar tamamlanarak 1946 yılında 50'şer öğrenci ile eğitime başladı. İstanbul Tıp Öğrenci Yurdu da ilk sinıfina 124 tıp, 9 eczacılık bölümü öğrencisi aldı. (BCA.30.10.14.80.18) İstanbul Ebe yurdu 11, Balıkesir köy ebe okulu 100, Konya köy ebe okulu da 45 öğrenci alarak eğitim faaliyetini sürdürdü.

\section{Sağlık İşlerinde Çalıştırılacak Personelin Yetiştirme Çalışmaları}

$\mathrm{Bu}$ dönemde doktorların ihtisaslarını düzenleyecek bir tüzüğ̈̈n tasarısı hazırlamaktaydı Tüzüğü hazırlamak için Ankara ve İstanbul Tıp fakültelerinden bir kısım profesörlerin de katıldığı bir komisyon oluşturuldu. Ayrıca Sağlık teşkilatında çalışan doktorların gelişimini sağlamak üzere kurslar açılmıştı. Bu bağlamda Hijyen Okulunda 1. Tekamül kursu açılarak hastane doktorları, sağlık merkezi ve sıtma Savaşı ile mücadele eden doktorlar bu kursa katıldı. 4 ay süren bu kurs tamamlanınca ikinci bir kursta daha açıldı. 1946 yılında da 80 sağ lık memuru kurs görmekte ve 1947 yılı içerisinde ihtiyaca yetecek miktarda doktor yetiştirilmesi düşünülmekteydi. Sağlık Bakanlığının tamamen yeni bir görüş olarak ele aldığı sağlık elemanları yetiştirme projesi tüm zorluklara ve ekonomik sıkıntılara rağmen başarılı olmuştu.

Tablo 6: 1945-1950 Y1lları Sağlık Personeli Sayıs1

\begin{tabular}{|c|c|c|}
\hline İsim & 1945 & 1950 \\
\hline Doktor & 3886 & 4870 \\
\hline $\begin{array}{l}\text { Doktor Başına Düşen } \\
\text { Nüfus }\end{array}$ & 6895 & 3020 \\
\hline Ebe & 806 & 1285 \\
\hline Diş Hekimi & ---- & 910 \\
\hline Eczacı & 725 & 980 \\
\hline Hemşire & 409 & 737 \\
\hline Sağlık Teknisyeni & 1632 & 4018 \\
\hline
\end{tabular}

Kaynak: BCA. 30.10.179.236.11 
Bu dönemde özellikle hemşirelerin durumu hemşire sayısına olan ihtiyaçtan dolayı öncelikli olarak ele alınmıştı. Bu amaçla toplumda hasta bakan bir hemşire profilinden başka terbiye eden, sağlık ve genel kültür yönünden aydınlatan, koruyan, düzenleyen, gebeye, çocuğa anneye, gençliğe işçiye ve işyerlerine ve hatta sağlık okullarında görev yapabilecek donanıma sahip hemşire modelini uygulamaya çalışmışlardı. Köy ebeleri, sağlık korucuları bu dönemde sağlıkta yeterli bir sayıya ulaşmıştı. (BCA. 30.10.179.236.11 )Yetiştirilen personel 1947 yılında ülkenin çeşitli bölgelerinde işe başlamışlardı.

$\mathrm{Bu}$ dönemde Köy Enstitülerinde de sağlık ile ilgili elemanlar yetiştirilmekteydi. Köy enstitülerinde yetiştirilmekte olan sağlık korucularının 1947 yılındaki mezunları 275 idi. 1948 senesinde ebe sayısı artarak bu sayı 360'a ulaştı. 1948 yılına kadar yetiştirilen köye ebe sayısı ise 500 civarındaydı. Sonraki yıllarda ebe sayısının her yıl 150 kişi artacağı planlanmıştı. İstanbul Ebe Merkezi de çalışmalarını düzenli olarak sürdürmekteydi. İstanbul'daki sağlık memuru Mektebi kadrosu 1946 yılından itibaren iki kat arttırılmış ve ders dönemi üç yıla çıkarılmıştı Ayrıca sağlık komiseri ünvanı ile yetiştirilecek olan öğrencilere lise mezunu olma hakkı tanındı. Sivas ve Diyarbakır'da ayrıca 50 kişilik sağlık Komiserliği Okulu açıldı. Bu okullardan mezun olan Sağlık komiserleri doktorların yardımcısı olarak görev yapmaktaydılar. (BCA. 30.10.179.236.11)

$\mathrm{Bu}$ dönemde Kızılay teşkilatı hemşirelerinin sayısını ülkenin ihtiyaç duyduğu miktarda artırmak için çalışmalar yapmaktaydı. Ayrıca Sağlık ve Sosyal Yardım Bakanlığı hemşire sayısını artırmak için Kızılay kurumunun da içinde olduğu geniş katılımlı bir program hazırlamıştı. Ülkenin yedi ilinde kurulacak olan hemşire okullarıyla hemşire açığı karşılanacaktı. Ayrıca hemşirelerin durumundan hariç doktorların durumuna da bu dönemde oldukça önem verilmişti. Tıp Doktoru yetiştiren eğitim kurumlarına 1946 yılında Ankara Tıp Fakültesi katılmıştı. Bu okullar vasıtasıyla doktor ihtiyacının karşılanması amaçlanmıştı.

\section{Sosyal Yardım İşleri}

Sosyal Yardım anlamında ihtiyacı olan çocukların eğitilmesi anlamında çalışmalar yapılmaktaydı. Kimsesiz terk edilmiş ve anormal çocukların korunması hakkındaki kanun tasarısı diğer bakanlıkların görüşleri de alınarak 6 Kasım 1947 tarihinde Büyük Millet Meclisine sunuldu. Kanun tasarısına göre Yoksulluk ve bakımsızlıktan veli veya vasilerinin aciz ve kusurlarından veya herhangi bir sebeple gözetme korunma eksikliğinden dolayı beden ruh ve ahlak gelişmeleri tehlikede bulunan kimsesiz terk edilmiş ve anormal çocukların 18 yaşında bitinceye kadar korunması, bakımı, yetiştirilmesi ve iş sahibi edilmesi Sağlık ve Sosyal Yardım Bakanlığı'na aitti

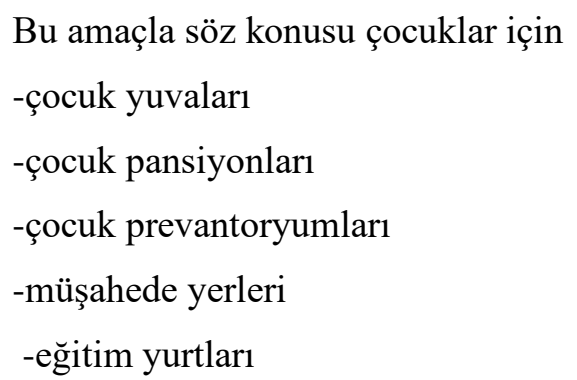

-kör sağır dilsiz ve sakatlar okul ve evleri açılmaya çalışıldı. Bu açılacak kurumların program ve yönetmelikleri Milli Eğitim Bakanlığı ile birlikte hazırlanacaktı. Bu kurumlarda ders verecek öğretmen ve öğrencilerden aranacak nitelikler de Milli Eğitim ve Sağlık ve Sosyal Yardım Bakanlıklarınca belirlenecekti. Bu dönemde ayrıca 10 yıllık milli sağlık planı ve nüfus siyasetini desteklemek amacıyla gerekli tedbirler almaya çalışmıştı. Alınan tedbirler arasında

1-nüfus siyaseti ve ekonomik kalkınma bakımından olumlu sonuçları açıkça ortaya çıkan koruyucu hekimlik teşkilatını bütün yurda kurmak ve yaymak 

bağlamak

2- sağlık teşkilatına köylünün ayağına kadar götürmek ve köy guruplarını sağlık ünitelerine

3-mevcut sağlık personelini ve bundan sonra yetişecek olanları ihtiyaçlarına uygun bilgi ve faaliyet standardına eriştirmek

4- Bütün yurdu kapsamak üzere çeşit bölgelerde tam teşkilatlı sağlık tesisleri kurmak ve bunların faaliyet sahasını kendilerine tahsis edilen bölgelerde merkezden muhite doğru yaymak

Yukarıda belirtilen sağlık ihtiyaç ve hizmetlerini karşılamak üzere de 200 milyon lira sermayeli bir milli sağlık sigorta merkez kurumu kurulması tasarlanmıştı. Kurumun sağlık sigorta sandıklarının yılda getirecekleri 15 milyon, hastane tedavi ücretlerinden gelecek 10 milyon ve devletçe yılda verilecek 40 milyon lira ödenekle finanse edilmesi amaçlanmıştı. (BCA.30.10.14.80.18)

\section{Sonuç}

Birinci Dünya Savaşı'ndan sonra Anadolu'nun itilaf devletlerince işgal edilmesi sonucu başlayan Kurtuluş Savaşı zaferle sonuçlanmış ve Anadolu düşman işgalinden kurtarılmıştı. Yeni kurulan Türkiye Cumhuriyeti her alanda olduğu gibi sağlık alanında da yaşanan ciddi sorunların çözümü için çalışmalara başladı. Türkiye' de sağlık hizmetlerinin devletin temel görevi olarak ele alınması Büyük Millet Meclisinin (BMM) açılmasıyla başladı. 23 Nisan 1920'de açılan BMM, 2 Mayıs 1920 tarihinde kabul ettiği 3 numaralı kanunla, Sıhhiye ve Muaveneti İçtimai (Sağlık ve Sosyal Yardım) Bakanlığı`nı kurarak sağlık hizmetlerinin yürütülmesi görevini bu bakanlığa devretti. Sağlık Bakanlığı’nın kurulmasından sonra ilk Sağlık Bakanı olarak Dr. Adnan Adıvar bakan olarak görevlendirildi. Dr. Adnan Adıvar, 11 Mayıs 1920 tarihinde Ankara vilayet konağının bir odasında bakan olarak görevine başladı. Dr. Adnan Adıvar ilk olarak, ülkede görev yapan hekimlerin sayısını tespit ederek İstanbul Hükümetinin sağlık işleri ile ilgili bütün kanun ve nizamnamelerini incelemeye başladı. Bu kapsamda Cumhuriyetin ilk yıllarında sağlık teşkilatının oluşturulması için gerekli olan kanunlar da çıkarılarak uygulamaya konuldu. Bunun yanı sıra bulaşıcı hastalıklarla mücadele, koruyucu sağlık hizmetlerinin geliştirilmesi ve ihtiyaç duyulan sağlık personelinin yetiştirilmesi çalışmaları yapıldı. Sonraki yıllarda sağlık hizmetlerinin ülkenin her yerine yaygınlaştırılması çalışmaları kapsamında köylere sağlık evi, ilçelere sağlık ocağı ve il merkezlerine hastane açılması çalışmaları yapıldı. Ayrıca bu sağlık kuruluşlarına sağlık personeli görevlendirme çalışmaları devam etti.

Türkiye'de sağlık çalışmaları II. Dünya Savaşı sırasında daha da önem kazanmaya başladı. Türkiye her ne kadar II. Dünya Savaşı'na katılmamış olsa da sağlık sosyal ve ekonomik alanda önemli zorluklarla karşılaşmıştı. Yaşanan bu zorluklar halk sağlığını olumsuz etkilemiş, yaşam kalitesinde düşüşe neden olmuştu. Ortaya çıkan beslenme yetersizlikleri ve evlerin sıhhi durumlarının uygun olmayışı verem hastalığ 1 başta olmak üzere salgın hastalıkların yayılmasını hızlandırmıştı II. Dünya Savaşından sonra sağlık alanında yaşanan önemli gelişmeler 1946-1950 yılları arasında bakanlık görevini yürüten Dr. Behçet $U z$, tarafindan hazırlanarak yürürlüğe giren "Birinci On Yıllık Sağlık Planı" ışığında uygulanmaktaydı. Bu planla sağlık hizmetleri entegre edilerek ülke sathına yayılması amaçlandı. Ayrıca sağlık hizmetlerinin tümü hükümetin görev ve sorumluluğu altına alındı. Plana göre, ülke yedi sağlık bölgesine ayrılacak ve her bölgenin örgütlenmesi kendine yeterli hale getirilecekti. Bu bölgelerde 40 köy için 10 yataklı bir sağlık merkezi kurulacak ve bu merkezlere 2 hekim, 1 ebe, 1 sağllk memuru ve bir ziyaretçi hemşire görevlendirilecekti. Ayrıca her 10 köy için bir ebe ve bir sağlık memuru görevlendirilecekti. Bu dönemde sağlık ile hazırlanan çalışma programında ana kurum sağlık merkezleri olmuştu. Her türlü sabit ve gezici vasıtalarla halk sağlığını koruma malzeme ve tertibatına sahip olacak bu merkezler aynı zamanda bütün ilk yardım araç ve elemanlarıyla teçhiz edilmiş olarak köyde köylünün yanında hizmete girerek ve kademe kademe yükselerek ülkenin dört yanında fennin bütün vasıta ve 
imkanlarını içinde toplayan en modern oluşumlarla Türk vatanında Türk vatandaşının İtimat ve güvenini korumaya çalışacaktı.

Bu dönemde Türkiye Cumhuriyeti'ni sağlık alanında bekleyen en büyük sorun, bulaşıcı hastalıkların neden olduğu salgın hastalıklardı. 1946 yılından itibaren ülkede Tifüs, Tifo Çiçek, At vebası ve benzeri bulaşıcı hastalıklarla mücadele için Sağlık Bakanlığı gerekli gördüğü her tedbiri almaya çalışmıştı. Bakanlık kurumlarında çok miktarda tifo ve çiçek aşısı bulunmaktaydı. İllerde bulaşıcı hastalıklar uzmanları dolaşmakta ve hastalık görülen yerlerde derhal sık1 tarama ve müdahale yapmaktaydı. Ülkemizde belli bir bölgede sık görülen bu hastalıkların normal seviye üstüne çıkması üzerine bakanlık halkı ikaz etmekte ve halkın aşılanmaya rağbet göstermesi bakanlığın mücadeledeki işini kolaylaştırmaktaydı. Tifüs hastalığı ile mücadele için de gerekli alanlarda ekipler hazırlanmış ve 6 milyon kişilik aşı stok edilmişti. Ayrıca D.D.T ile gerekli yerlerde bit mücadelesi yapılmaktayd.

Salgın hastalıklar konusunda halkı bilinçlendirmek amacıyla bakanlık tarafından "Sağlık Propaganda" isimli neşriyat yayınlandı. Bu neşriyattan sonra "Su hijyeni. Kuduz Hastalığı ve Korunma Yöntemleri" isimli broşüler de yayınlanarak şehir, kasaba ve köylerdeki halka, ordu mensuplarına okullara, halk ve işçi toplulukları bulunan resmi ve özel kurumlara ücretsiz dağıtıldı. Ayrıca salgın hastalıklarla mücadele etmek amacıyla yabancı bilim adamlarıyla da ortak çalışma yürütülmekteydi. Bu bağlamda İngiliz uzman Mr. R. Daubney ülkemize gelerek Tarım Bakanlığında Bakteriyoloji ve Seroloji konularında çalışmalara başladı.

Savaş sonrası yıllarda gerek kişi başına düşen yıllık harcamada gerekse Sağlık ve Sosyal Yardım Bakanlığına ayrılan bütçede belirgin bir yükselme yaşanmıştı. Sağlık alanında kamu harcamaları da 1946 yılından başlayarak düzenli bir artış göstermişti. Sağlık Bakanlığı bütçesi ise ilk kez 1950 yılında bütçenin \%4.4 üne ulaşmıştı. 1950 yılında bütçede sağlık için ayrılan ödenek 60.980.329 lira idi. Dolayısıyla 1946 yılı içerisinde bütçe harcaması \%3.23 olan SSYB, 1950 yılında \%4.15 e yükseldi. 1946 -1950 dönemindeki artış eğilim 1949 yılında belirgin biçimde arttı

$\mathrm{Bu}$ dönemde doktorların ihtisaslarını düzenleyecek bir tüzüğün tasarısı hazırlamaktaydı Tüzüğü hazırlamak için Ankara ve İstanbul Tıp fakültelerinden bir kısım profesörlerin de katıldığı bir komisyon oluşturuldu. Ayrıca Sağlık teşkilatında çalışan doktorların gelişimini sağlamak üzere kurslar açılmıştı. Bu bağlamda Hijyen Okulunda 1. Tekâmül kursu açılarak hastane doktorları, sağlık merkezi ve sıtma Savaşı ile mücadele eden doktorlar bu kursa katıldı. 4 ay süren bu kurs tamamlanınca ikinci bir kursta daha açıldı. 1946 yılında da 80 sağlık memuru kurs görmekte ve 1947 y1lı içerisinde ihtiyaca yetecek miktarda doktor yetiştirilmesi düşünülmekteydi. Sağlık Bakanlığının tamamen yeni bir görüş olarak ele aldığı sağlık elemanları yetiştirme projesi tüm zorluklara ve ekonomik sıkıntılara rağmen başarılı olmuştu.

Sosyal Yardım anlamında ihtiyacı olan çocukların eğitilmesi anlamında çalışmalar yapılmaktaydı. Kimsesiz terk edilmiş ve anormal çocukların korunması hakkındaki kanun tasarısı diğer bakanlıkların görüşleri de alınarak 6 Kasım 1947 tarihinde Büyük Millet Meclisine sunuldu. Kanun tasarısına göre yoksulluk ve bakımsızlıktan veli veya vasilerinin aciz ve kusurlarından veya herhangi bir sebeple gözetme korunma eksikliğinden dolayı beden ruh ve ahlak gelişmeleri tehlikede bulunan kimsesiz terk edilmiş ve anormal çocukların 18 yaşında bitinceye kadar korunması, bakımı, yetiştirilmesi ve iş sahibi edilmesi Sağlık ve Sosyal Yardım Bakanlı̆̆ı'na aitti.

$\mathrm{Bu}$ çalışmada Türkiye'nin II. Dünya Savaşından sonra sağlık politikasının nasıl oluşturulduğu, salgın hastalıklara karşı ne gibi önlemler alındığı, devletin ve halkın salgın hastalıklar ile ilgili mücadele yöntemleri tespit edilmeye çalışılmıştır. Özellikle Cumhuriyet Arşivi’nden yararlanılarak konu ile ilgili ulaşılabilen kaynaklar değerlendirilmiştir. Ayrıca Türkiye Büyük Millet Meclisi Tutanak Dergisindeki konuşma zabıtları doğrultusunda milletvekillerinin sağlık alanında yaptığı çalışmalar değerlendirilmiştir. 


\section{Kaynakça}

\section{Arşiv Kaynakları ve Resmi Yayınlar}

Başbakanlık İstatistik Genel Müdürlüğü(BİGM). (1937). İstatistik Yıllığı 1936-1937.

Başvekâlet İstatistik Umum Müdürlüğü (BİUM). (1929). İstatistik Yı1lı̆̆ı (C.II), Cumhuriyet Matbaas1.

BCA. 30.18.1-2.121.83.13

BCA. 30.10.178.228.10

BCA. 30.10 .14 .80 .18

BCA. 30.10.186.284.5

BCA. 30.10.179.236.11

BCA.30.10.177.224.12

BCA.30.18.1-2.107.106.17

BİGM. (1948). İstatistik Yıllığı 1948(C.16).

BİGM. (1951). İstatistik Y1llı̆̆ 1951.

BİGM. (1950).Türkiye İstatistik Yıllığ 1950 (C.18).

BİUM. (1941). İstatistik Y1llığ 1940-1941(C.12).

Resmi Gazete, 21 Şubat 1946 S.6238

(Resmi Gazete, 16.07.1945) No: 6058

TBMMZC, 6/79/551, Ankara, 1947

TBMMZC, I. Dönem, C.14/B.119. Ankara, 1922

TBMMZC, IX. Dönem, C.12/B.23. Ankara, 1950

TBMMZC, IX. Dönem, C.15/B.73. Ankara, 1950

TBMMZC, XI. Dönem, C.13/B.52.Ankara, 1950

TBMMZC, I. Dönem, C. I / B. 9.Ankara,1921

\section{Araștırma Eserler}

Kitap ve Makaleler

Ak, B. (2002). Türkiye Cumhuriyeti`nde Sağlık Hizmetleri. Ankara: Türkler (C.17), Yeni Türkiye Yayınlan1

Akdur, R. (1999). Türkiye Cumhuriyeti ’nin 75. Yılında Türkiye’de Sağlık Politikaları. Türkiye Bilimler Akademisi Türkiye Cumhuriyeti nin 75.Yılında Bilim (Bilanço 1923-1998) Ulusal Toplantis1

Akdur, R. (2006). Sağlik Sektörü “Temel Kavramlar, Türkiye ve Avrupa Birliği’nde Durum ve Türkiye`nin Birliğe Uyumu”. Ankara Üniversitesi Basımevi

Albayrak, M. (2004), Türk Siyasi Tarihinde Demokrat Parti (1946-1960)

Aşgın, S, (2000) Cumhuriyet Döneminde Doğu Anadolu'ya Yapılan Kamu Harcamaları (19461960). 
Fişek, N. H. (1983). Halk Sağlığına Giriş. Hacettepe Üniversitesi Dünya Sağlık Örgütü Hizmet Araştırma ve Araştıııcı Yetiştirme Merkezi Yayını, Yayın No:2.

Dirican, M.R. (1970). Türkiye'de Sağlık Hizmetlerinin Örgütlenmesinin Kısa Tarihçesi. Atatürk Üniversitesi Tıp Fakültesi Tıp Bülteni, C. 2, S.7

Goloğlu, M. (1982) Demokrasiye Geçiş, 1946-1950.

Kasapoğlu, A. (2016).Türkiye'de Sağlık Hizmetlerinin Dönüşümü. Sosyoloji Araştırmaları Dergisi, 19(2), 131-174.

Kopar, M, (2009), Cumhuriyet Halk Partisi Döneminde Doğu Anadolu'ya Yapılan Kamu Harcamaları ve Yatırımlar (1927-1950), Ankara Nadi, N, Sağlık Planı, Cumhuriyet 15 Aralık 1946.

Nesipoğlu, G. (2008). Olgusal Bir Yapı Olarak Sağlık Politikaları: 1920-1960 Yılları Aras1 Cumhuriyet Döneminin Tarihsel İzleği. Hacettepe Sağlık Dergisi, 21(2), 165-177.

Özpekcan, M. (2002). TBMM Tutanaklarına göre Cumhuriyetin ilk 10 Yılında Sağlık Politikaları. Ankara: Türkler, C.17,Yeni Türkiye Yayınları.

Gürsoy, G. (1983), Türkiye Ansiklopedisi, C.VII, İletişim Yayınları, 1716-1730.

80. Yılda Tedavi Hizmetleri (1923-2003). (2004). Sağlk Bakanlığı Tedavi Hizmetleri Genel Müdürlüğ̈̈ 